\title{
PUSTAKAWAN SEKOLAH DAN LITERASI INFORMASI: MENJAWAB TANTANGANNYA GLOBALISASI
}

\author{
A. Rahmania Abidin \\ MAN 1 Ambon \\ *)E-mail: andiniasubair@gmail.com
}

\begin{abstract}
ABSTRAK
Makalah ini adalah sebuah refleksi kritis atas kompleksitas permasalahan perpustakaan sekolah secara umum di Indonesia dalam berhadapan dengan tantangan globalisasi dunia. Tantangan terbesar pada era globalisasi ialah perkembangan masyarakat harus selaras dengan kemajuan teknologi yang diikuti secara menyeluruh. Namun masih banyak kalangan yang kurang peduli akan perkembangan informasi. Oleh karena itu perlu ada pergerakan literasi informasi yang meningkatkan kemampuan literasi informasi pada kalangan ini sekaligus mempertahankan kualitas informasi literal kaum intelektual. Literasi informasi sebagai gerakan memposisikan pustakawan sebagai "agen" literasi dalam menyiapkan generasi yang melek informasi. Pustakawan, dalam hal ini pustakawan sekolah, menuntun pemustaka (siswa) untuk memilih dan menentukan informasi yang paling dibutuhkan dengan skala prioritas. Posisi tersebut tentu saja sangat sulit dan menuntut keahlian sehingga pustakawan selain harus memiliki pemahaman tentang pentingnya literasi informasi juga harus terus menerus meningkatkan kualitas sumber dayanya. Tenaga perpustakaan harus memiliki kemampuan mengajar, senantiasa memperbaharui pengetahuan (willingness to learn) dan memiliki kemampuan praktis serta selalu berupaya mengikuti perkembangan literasi informasi. Kualitas tidak hanya terbatas dalam kemampuan dalam menguasai pengetahuan saja tetapi juga mampu memahami peran serta perubahan yang terjadi secara cepat. Dengan kemajuan teknologi informasi peran pustakawan akan mengalami perubahan. Pustakawan dapat menjalankan peran barunya tetapi tidak harus meninggalkan peran kepustakawanannya. Keterampilan ini dapat diperoleh melalui pengajaran keterampilan literasi informasi. Semua keterampilan merupakan bagian dari tanggung jawab pustakawan di sekolah.
\end{abstract}

Kata Kunci: pustakawan, perpustakaan sekolah, literasi informasi, globalisasi, pasar bebas

\section{PENDAHULUAN}

Istilah Globalisasi sudah dibicarakan dan didengar saat dunia akan memasuki milenium ketiga (dasawarsa 1990-an), bahkan jauh sebelumnya. Banyak pemikir abad ke-19 yang mengindentifikasi munculnya hubungan Eropa dengan dunia luar Eropa, dalam arti upaya Eropa mendominasi dunia luar Eropa melalui perdagangan dan industri yang dikatakannya sebagai proses universal. Upaya membuat dan meyakinkan dunia luar Eropa dengan konsep Eropa itulah sebenarnya awal dari globalisasi. Selanjutnya globalisasi menyusutkan dunia yang kecil menjadi sangat kecil namun sekaligus menjadi kekuatan baru yang ditemukan untuk bekerjasama dan bersaing secara individual di kancah global. Fenomena tersebut oleh Friedman dikatakan sebagai tatanan dunia datar (flat-world-platform) yaitu konvergensi antara komputer pribadi dimana setiap individu dapat menjadi komunikator sekaligus komunikate tanpa menghiraukan jarak antar mereka, sehingga memungkinkan mereka secara bersama-sama mengerjakan suatu materi digital atau berbagi informasi secara online. ${ }^{1}$ Kekuatan individu dan kelompok-kelompok kecil sebagai motor penggerak globalisasi semakin nyata dengan adanya mesin pencari seperti google, yahoo dan lain-lain serta maraknya jejaring sosial seperti facebook, twitter dan lain-lain. Mereka secara individual maupun berkelompok menghilangkan batas negara untuk berinteraksi, membahas dan menyelesaikan satu masalah yang sama bersama-sama.

Era globalisasi disebut juga dengan era informasi karena saat ini lebih pada perang

${ }^{1}$ Friedman, T.L. 2006. The World is Flat: Sejarah Ringkas Abad Ke-21. Jakarta: Dian Rakyat. H. 10. 
teknologi terutama teknologi informasi yang semakin keras. Dampak yang sangat nyata dari kemajuan teknologi informasi adalah terjadinya situasi yang disebut dengan ledakan informasi, yaitu situasi yang setiap orang dapat menerima informasi apa-pun, kapan-pun dan dari manapun tanpa batas. Hal ini meniscayakan bagi setiap orang untuk memiliki keterampilan dan pengetahuan melakukan pencarian informasi yang benar, sehingga akan diperoleh informasi yang benar-benar sesuai dengan kebutuhannya. Agar proses pemenuhan kebutuhan informasi berhasil dengan baik, maka seseorang perlu memahami konsep literasi informasi (information literacy).

Hadirnya informasi yang begitu beragam dan dalam jumlah yang begitu besar secara terus menerus ternyata tidak selalu membuat hidup menjadi lebih mudah. Memilih dan menentukan informasi yang paling dibutuhkan dengan skala prioritas ternyata sulit dan butuh keahlian. Globalisasi amat membutuhkan hadirnya seseorang yang memiliki kompetensi mengelola informasi agar informasi yang tepat dapat sampai pada orang yang tepat, pada waktu yang tepat, dan dengan format dan cara yang tepat, serta di tempat yang tepat pula. Orang bijak mengatakan bahwa keputusan yang tepat diambil atas dasar informasi yang tepat. Dalam konteks inilah dibutuhkan peran pustakawan.

Literasi informasi berhubungan erat dengan tugas pokok pelayanan perpustakaan. Dalam perkembangannya, para pustakawan terutama pustakawan pada perpustakaan sekolah, umumnya memandang keterampilan yang hendak dikembangkan dalam program literasi informasi adalah berupa keterampilan yang tidak mengundang permasalahan (nonproblematis). Akan tetapi dalam perkembangan selanjutnya, program- program pelatihan literasi informasi diperluas menjadi pelatihan tentang dunia teks pada umumnya yaitu bagaimana cara yang efektif dan efisien untuk mencari dan menemukan dokumen dari perpustakaan, selanjutnya ditambah dengan penumbuhan budaya digital agar mampu dan terbiasa melakukan akses terhadap berbagai sumber daya informasi elektronik. Akses terhadap sumberdaya informasi elektronik saat ini sudah menjadi keharusan mengingat volume informasi dalam format elektronik yang tersedia saat ini diperkirakan jauh melebihi informasi yang tersedia dalam format tercetak. Akibatnya, proses pembelajaran harus memanfaatkan informasi dalam format elektronik.

Dewasa ini berbagai lembaga pendidikan mulai dari jenjang pendidikan dasar sampai dengan pendidikan tinggi ada yang mulai, sedang, dan telah membangun program literasi informasi. ${ }^{2}$ Tujuannya salah satunya ialah membentuk generasi yang melek informasi. Seseorang yang sudah melek informasi dianggap akan mampu menjelajahi lautan dan belantara informasi yang semakin lama semakin luas dan rumit, baik yang menggunakan sumber-sumber tercetak maupun yang elektronik. Program penguasaan literasi informasi dianggap dapat menciptakan keberaksaraan yang berbasis keterampilan (skills-based literacy). Termasuk di dalam keterampilan ini adalah kemampuan mencari informasi, memilih sumber informasi secara cerdas, menilai dan memilah-milah sumber informasi, menggunakan serta menyajikan informasi secara etis. Orang yang melek informasi adalah orang yang mampu menyadari kapan informasi diperlukan dan ia juga mempunyai kemampuan untuk menemukan, mengevaluasi dan menggunakan informasi tersebut secara efektif (American Library

${ }^{2}$ Hasugian. J. 2008. Urgensi Literasi Informasi dalam Kurikulum Berbasis Kompetensi di Perguruan Tinggi Pustaha: Jurnal Studi Perpustakaan dan Informasi, Vol. 4, No. 2, Desember 2008. 
Association, 1998). Literasi informasi juga merupakan pra-syarat dalam masyarakat informasi dan merupakan hak asasi manusia untuk belajar sepanjang hayat. ${ }^{3}$

Makalah ini adalah sebuah refleksi kritis atas kompleksitas permasalahan perpustakaan sekolah secara umum di Indonesia dalam berhadapan dengan tantangan globalisasi dunia, termasuk di dalamnya rencana pemberlakukan perdagangan bebas Asia (AFTA). Penulis menawarkan solusi "gerakan literasi informasi" dengan pustakawan sekolah sebagai "agen" literasi dalam menyiapkan generasi yang melek informasi. Termasuk dalam pembahasan makalah ini tantangan-tantangan yang akan dihadapi oleh pustakawan sebagai satu profesi dalam dunia kerja yang terbuka dan bebas.

\section{Konsep Umum Literasi Informasi}

Literasi berasal dari Bahasa Inggris literacy yang berarti kemampuan untuk membaca dan menulis. Litteracy berasal dari kata latin littera yang berarti letter atau huruf, sehingga literacy sering diterjemahkan sebagai melek-huruf dan illiteracy sebagai buta-huruf. Literate sendiri juga dapat juga diartikan sebagai educated yang berarti terdidik atau berpendidikan. Hal ini dikarenakan untuk menguasai bahasa tulis seseorang perlu mendapatkan pendidikan dari orang lain, selain itu dengan menguasai bahasa tulis seseorang mampu mengakses berbagai pengetahuan dan informasi untuk memperkaya pengetahuannya.

Pengertian luas literasi sebagai terdidik, mengakibatkan kata literasi banyak digunakan untuk berbagai istilah, termasuk juga istilah literasi informasi. Ada banyak sekali pandangan dan definisi mengenai literasi informasi. Berbagai pandangan tersebut dapat kita kelompokan menjadi dua bagian, yang

${ }^{3}$ Perpustakaan Nasional RI. 2007. UndangUndang Republik Indonesia Nomor 43 tahun 2007 Tentang Perpustakaan. H. 15. pertama dari sudut pandang kompetensi individu dan yang kedua dari sudut pandang hak asasi manusia dan kemasyarakatan.

Kedua sudut pandang tersebut bertemu pada pemahaman mengenai pentingnya informasi dalam kehidupan manusia, baik dalam kehidupan individu maupun kehidupannya bermasyarakat.

\section{Sudut Pandang Keterampilan dan Kompetensi lndividu}

Sudut pandang ini bermula dari kegiatan dalam bidang ilmu perpustakaan dan studi informasi. Pada awalnya literasi informasi dipahami sebagai pendidikan bibliografis atau petunjuk orientasi perpustakaan. Dengan pendidikan ini diharapkan setiap peserta didik dapat memanfaatkan layanan yang diberikan oleh perpustakaan beserta peraturanperaturannya, memahami bagaimana pengorganisasian koleksi, penyusunan subjek dan kelas, sistem klasifikasi yang digunakan, dapat melakukan pencarian dengan menggunakan katalog dan database, cara peminjaman ke perpustakaan lain (inter-library loan), dan dapat memanfaatkan koleksi dalam berbagai format seperti buku, periodikal, mikrofilm, CD/DVD, dan lain sebagainya. Tujuan dari pendidikan ini adalah agar pengguna dapat memperoleh informasi yang diperlukan secara efektif melalui perpustakaan.

Konsep ini kemudian berkembang dari pendidikan orientasi perpustakaan menjadi pendidikan keterampilan untuk dapat mencari dan memanfaatkan informasi, tidak hanya melalui perpustakaan tapi juga melalui sumbersumber informasi lain. Keterampilan ini dipandang bermanfaat dalam proses pemecahan masalah, proses belajar mandiri dan proses pendidikan sepanjang hayat.

Ada banyak definisi literasi informasi dari sudut pandang ini, sebagai contoh definisi 
menurut ALA (American Library Association) dan definisi yang digunakan oleh APISI (Asosiasi Pekerja Informasi Sekolah Indonesia). Literasi informasi menurut ALA adalah:

"To be information literate, a person must be able to recognize when information is needed and have the ability to locate, evaluate, and use effectively the needed information". (Presidential Committee on Information Literacy. 1989, p. 1).

Naiboho mengartikan bahwa literasi informasi diartikan sebagai kemampuan seseorang untuk mengidentifikasi informasi yang dibutuhkannya, mengakses dan menemukan informasi, mengevaluasi informasi, dan menggunakan informasi secara efektif dan etis.

Karena informasi dapat disajikan dalam berbagai bentuk, istilah informasi tidak hanya mengacu pada media cetak saja. Literasi lain seperti literasi visual, literasi media, literasi komputer, literasi jaringan adalah literasi mendasar yang secara implisit termasuk dalam literasi informasi.

Definisi literasi informasi yang digunakan APISI adalah:

"Literasi informasi adalah seperangkat ketrampilan untuk mendapatkan jalan keluar dari suatu masalah yang ada. Ketrampilan ini mencakup ketrampilan mengidentifikasi masalah, mencari informasi, menyortir, menyusun, memanfaatkan, mengkomunikasikan dan mengevaluasi hasil jawaban dari pertanyaan atau masalah yang dihadapi tadi".

Definisi ini disusun dari tahapan penggunaan informasi untuk memecahkan suatu masalah, setiap tahapan membutuhkan keterampilan yang spesifik. Sudut pandang keterampilan atau kompetensi adalah sudut pandang utama dalam menjelaskan dan memahami literasi informasi.

\section{Sudut Pandang Hak Asasi Manusia dan} Kemasyarakatan

Sedikit berbeda dengan pandangan sebelumnya yang lebih menekankan pada keterampilan individu, pandangan ini lebih menekankan pada peran literasi informasi dalam kehidupan bermasyarakat. Literasi informasi diterjemahkan sebagai kemampuan dialog individu dalam masyarakat informasi. Dalam definisi lain, literasi informasi diartikan sebagai sekumpulan kemampuan individu untuk dapat turut serta aktif dalam masyarakat informasi.

Masyarakat informasi adalah masyarakat yang dalam tata kehidupannya, informasi dan pengetahuan berperan penting dalam berbagai segi kehidupan, baik dalam kegiatan, ekonomi, politik, sosial, maupun budaya. Dalam pandangan ini, kebebasan dan kemampuan untuk memperoleh dan menyampaikan informasi tidak dipandang sebagai keterampilan individu semata tetapi juga dipandang sebagai hak asasi individu yang harus dijamin oleh negara manapun.

Untuk dapat memahami literasi informasi sebagai ketrampilan dan juga hak asasi manusia, kita dapat mengambil pemahaman dari kata dasar literasi itu sendiri. Literasi atau kemampuan baca-tulis dapat dilihat sebagai ketrampilan individu, dapat juga dipandang sebagai hak individu untuk memperolehnya. Hak ini diakui dalam hak untuk memperoleh pendidikan dan pengajaran. Hal yang sama dapat kita lihat pada literasi informasi, literasi informasi dapat dipandang sebagai keterampilan sekaligus juga dapat dipandang sebagai hak asasi individu untuk dapat menguasainya. Pengakuan negara akan hak asasi manusia harus disertai dengan upaya untuk memastikan hak-hak tersebut terpenuhi. Misalnya suatu negera mengakui hak untuk 
mampu membaca dan menulis bagi setiap individu, tapi jika itu tidak diiringi dengan sarana, kesempatan dan pendidikan untuk melakukan hak-hak tersebut, berarti negara secara tidak langsung telah mengabaikan hakhak asasi individu tadi. Hal yang sama juga terjadi pada hak literasi informasi, negara harus melakukan segala usaha untuk mewujudkan literasi informasi di masyarakat.

Terkait dengan kebermasyaraktan, dalam masyarakat terliterasi informasi, setiap individu bebas untuk menerima atau tidak menerima informasi yang disampaikan oleh siapapun. Masyarakat yang telah terliterasi informasi akan tidak mudah termakan isu, fitnah dan propaganda. Setiap orang mempunyai kemampuan untuk mencari dan memproses informasi yang diterimanya, bisa membedakan antara opini atau pendapat dengan fakta atau kenyataan. Selain itu, setiap orang juga tidak akan sembarangan menyebarkan isu, fitnah, berita bohong, dan bersaksi palsu, karena setiap informasi yang disampaikan dapat diperiksa dan dapat dipertanggung jawabkan di depan publik dan hukum. Dengan kemampuan literasi informasi dari setiap individu maka akan tercipta suatu masyarakat informasi.

Kata literasi dewasa ini tidak lagi diasosiasikan dengan "baca tulis" melainkan dengan belajar sepanjang hayat. Berbagai definisi literasi informasi bermunculan. Banyak definisi tentang literasi informasi digunakan oleh para pakar, dalam pengertian yang sederhana, literasi informasi sebagai kemampuan untuk mengakses, menilai dan menggunakan informasi dari berbagai sumber. Menurut Unesco literasi informasi merupakan kemampuan untuk menyadari kebutuhan informasi dan saat informasi diperlukan, mengidentifikasi dan menemukan lokasi informasi yang diperlukan, mengevaluasi informasi secara kritis, mengorganisasikan dan mengintegrasikan informasi ke dalam pengetahuan yang sudah ada, memanfaatkan serta mengkomunikasikannya secara efektif, legal dan etis.

Definisi lainnya dari literasi informasi yaitu mengarahkan pengetahuan akan kesadaran dan kebutuhan informasi seseorang, dan kemampuan untuk mengidentifikasi, menemukan, mengevaluasi, mengorgamsasi dan secara efektif menciptakan, menggunakan, mengkomunikasikan informasi untuk mencari solusi atas masalah yang dihadapi. Literasi informasi juga merupakan persyaratan untuk berpartisipasi dalam masyarakat informasi, dan merupakan hak asasi manusia untuk belajar sepanjang hayat. ${ }^{4}$

Dengan demikian, literasi informasi dapat dipahami sebagai sebuah kemampuan untuk memahami betapa pentingnya informasi, bagaimana memperoleh informasi melalui sumber-sumber informasi yang valid dan berguna untuk mencari solusi dari suatu permasalahan dalam kehidupan. Literasi informasi membutuhkan kemampuan analisis, kreatifitas dan daya kritis dari pengguna informasi. Setelah memperoleh informasi pengguna dituntut untuk dapat mempergunakannya secara efektif, efesien, dan beretika. Informasi yang diperoleh tersebut dapat dipergunakan atau dikomunikasikan baik secara tertulis maupun lisan. Hal yang terpenting adalah adanya transfer informasi dalam kehidupan nyata seseorang atau pengguna informasi yang membentuk sebuah pengetahuan baru baginya.

\section{Tantangan Umum Pustakawan (Sekolah) di Era Globalisasi}

Sebuah penelitian dengan responden ratusan sekolah yang berada di pulau Jawa, Bali dan Lombok dilakukan dengan

${ }^{4}$ Ibid. Perpustakaan Nasional RI. 2007. 
menanyakan tentang fasilitas perpustakaan dan sumber bahan bahasa yang ada di perpustakaan sekolah. Penelitian tersebut menemukan fakta bahwa:

1. Biasanya tidak ada siswa-siswi di dalam perpustakaan.

2. Perpustakaannya hanya buka padajam kelas (paling tambah 15 menit).

3. Guru-guru tidak secara rutin menyuruh siswa-siswi dalam jam kelas ke perpustakaan untuk tugas, mencari informasi atau solusi sendiri.

4. Jelas, guru-guru tidak dapat minta siswasiswi mencari informasi di perpustakaan di luar jam kelas karena perpustakaannya tidak buka.

5. Guru-guru sendiri jarang kunjungi perpustakaan, dan kurang tahu isinya.

6. Seringkali pengelola perpustakaan adalah guru yang juga jarang ada di perpustakaan.

7. Pada umumnya, pengelola perpustakaan kelihatannya tidak mempromosikan perpustakaannya (atau berjuang untuk meningkatkan minat baca) secara aktif dan kreatif.

8. Lingkungan sekolah (termasuk rakyat) kurang aktif membangunkan perpustakaan. ${ }^{5}$

Fakta dari hasil penelitian ini menunjukkan bahwa perpustakaan saat ini hanya menjadi "gudang buku" di sebuah sekolah. Kondisi ini tentu saja tidak terjadi pada semua sekolah yang ada di Indonesia. Namun, kondisi ini dialami oleh banyak sekolah di Indonesia. Beberapa sekolah unggulan atau swasta/intemasional mungkin saja perpustakaannya telah dikelola dengan baik, tapi tak jarang sekolah-sekolah unggulan dan swasta kita juga menemukan kondisi

${ }^{5}$ http://pendidikan.net/pemustakaan.html perpustakaan yang miris seperti hasil penelitian tersebut.

Masalah perpustakaan sekolah di Indonesia, terutama di wilayah luar Pulau Jawa memang sangat kompleks, apalagi jika dihadapkan dengan tantangan era globalisasi. Seperti telah dijelaskan sebelumnya bahwa abad ke-21 ditandai dengan globalisasi ekonomi, merupakan suatu proses kegiatan ekonomi dan perdagangan, di mana negara-negara di seluruh dunia menjadi satu kekuatan pasar yang semakin terintegrasi dengan tanpa rintangan batas teritorial negara. Masalah daya saing dalam pasar dunia yang semakin terbuka merupakan isu kunci dan tantangan yang tidak ringan. Tanpa dibekali kemampuan dan keunggulan saing yang tinggi niscaya produk suatu negara, termasuk produk Indonesia, tidak akan mampu menembus pasar internasional. Sementara di sisi lain Indonesia kekurangan berbagai keahlian untuk mengisi berbagai tuntutan globalisasi. Dengan begitu, seandainya bangsa Indonesia tidak bisa menyesuaikan terhadap pelbagai kondisionalitas yang tercipta akibat globalisasi, maka yang akan terjadi adalah adanya gejala menjual diri bangsa dengan hanya mengandalkan sumberdaya alam yang tak terolah dan buruh yang murah. Sehingga yang terjadi bukannya terselesaikannya masalah-masalah sosial ekonomi seperti kemiskinan, pengangguran dan kesenjangan ekonomi, tetapi akan semakin menciptakan ketergantungan kepada negara maju karena utang luar negeri yang semakin berlipat.

Kompleksitas

permasalahan perpustakaan sekolah dapat dijelaskan sebagai berikut.

\section{Aspek kelembagaan}

Tidak adanya kesatuan struktur perpustakaan merupakan bukti bahwa aspek kelembagaan perpustakaan sangat rapuh. Seperti 
diketahui bersama antara perpustakaan nasional, perpustakaan provinsi, dan perpustakaan umum tidak ada koordinasi struktural, melainkan sebatas koordinasi fungsional. Belum lagi dengan perpustakaan sekolah yang berada di bawah kewenangan Departemen/Dinas yang menaungi sekolah yang bersangkutan. Selama ini yang bertanggung jawab mengelola perpustakaan sekolah adalah guru yang disebut guru pustakawan dengan tugas ganda sebagai guru dan sebagai pengelola perpustakaan sekolah. Pada umumnya mereka tidak memiliki dasar pendidikan perpustakaan. Malahan ada kasus pemindahan guru bermasalah menganiaya siswa dipindahtugaskan menjadi mengelola perpustakaan sekolah. ${ }^{6}$ Hal ini menunjukkan masih kurangnya pemahaman pihak sekolah akan profesionalisme pustakawan.

Menurut Anthony (2002) agar pustakawan perpustakaan sekolah efektif, ia harus mempunyai tiga dasar pengetahuan yaitu: (1) pengetahuan pendidikan, (2) pengetahuan perpustakaan, dan (3) pengetahuan teknologi. Untuk itu di luar negeri yang dinamakan guru pustakawan bukanlah guru yang ditugaskan menjadi pustakawan sekolah, akan tetapi guru menambah pendidikannya lagi pada jurusan ilmu perpustakaan (a postgraduate course in school librarianship) atau setidaknya mengikuti pelatihan bidang ilmu perpustakaan. Sedangkan pustakawan dengan pendidikan ilmu perpustakaan untuk menjadi pengelola perpustakaan sekolah, harus mengikuti training kependidikan. Memberikan tugas pengelolaan perpustakaan kepada guru bukanlah suatu pemecahan masalah, dan perlu dikaji ulang. Guru yang memiliki tugas utama sebagai pengajar, diragukan kemampuannya untuk dapat mengembangkan perpustakaan sekolah secara maksimal. Hal ini terlihat di lapangan, bahwa

\footnotetext{
${ }^{6}$ http://staf.undip.ac.id/sastra/2009/07/2
}

perpustakaan sekolah akan tutup apabila guru dalam jadwal mengajar.

\section{Pendanaan}

Aspek kelembagaan yang lemah akan membawa dampak berupa minimnya anggaran yang dialokasikan oleh pemerintah di bidang perpustakaan. Bahkan tidak sedikit perpustakaan yang didukung dengan anggaran nol rupiah. Meskipun Undang-Unndang Perpustakaan sudah mewajibkan setiap sekolah untuk mengalokasikan minimal lima persen dari APBS untuk perpustakaan, realitas di lapangan hampir tidak ada perubahan.

\section{Sumber Daya Manusia (SDM)}

Pustakawan dan perpustakaan merupakan sesuatu yang tak terpisahkan, seperti dua sisi mata uang, dimana ada perpustakaan, maka idealnya disitu juga harus ada pustakawan. Namun pada kenyataanya, banyak sekali perpustakaan yang di dalamnya tidak ada pustakawan. Sehingga perpustakaan tidak dapat menjalankan tugas dan fungsinya dengan baik. Pustakawan merupakan ujung tombak bagi keberhasilan suatu perpustakaan dalam meningkatkan minat baca masyarakat. Tetapi profesi ini ternyata belum memperoleh perhatian yang layak dari pemerintah (terutama pemerintah daerah). Pada setiap rekrutmen CPNS, jarang sekali pemerintah daerah di Indonesia yang mengajukan formasi CPNS untuk jabatan fungsional pustakawan untuk para lulusan Sarjana dan Diploma III Perpustakaan. Padahal hingga saat ini jumlah pustakawan di kabupaten/kota di Indonesia masih sangat sedikit. Menurut faktor yang menyebabkan perpustakaan belum dapat berkembang dan masih belum bisa berdiri sendiri di antaranya adalah pengelola perpustakaan. Pengelola perpustakaan yang dimaksud adalah pustakawan sebagai penentu kemajuan sebuah perpustakaan. Dibutuhkan kemampuan yang luar biasa untuk memajukan sebuah perpustakaan. Berbagai 
tantangan dan rintangan menjadi bagian yang tak terpisahkan dalam perjuangan para pustakawan untuk memajukan perpustakaan. ${ }^{7}$

Dalam konteks globalisasi, pustakawan tidak cukup hanya menguasai keterampilan tentang pengelolaan perpustakaan belaka. Menurut Basuki (2006), bahwa jika berpegang pada konsep pustakawan professional dan menghadapi Asean Free Trade Area (AFTA), maka lambat atau cepat AFTA akan diikuti oleh pergerakan tenaga kerja lintas batas Negara seperti Uni Eropa sekarang. Oleh sebab itu pustakawan harus memiliki kemampuan keilmuan berbahasa minimal Inggris dan penguasaan teknologi. Oleh sebab itu, sangat penting bagi pustakawan untuk senantiasa manambah pengetahuan melalui pendidikan formal. Namun yang terjadi dilapangan terkadang sebaliknya, lembaga atau pimpinan seringkali berifikir instant mereka lebih senang mengirimkan tenaga non pustakawan yang memiliki ijazah sarjana non pustakawan untuk mengikuti diklat pustakawan yang hanya 4 bulan selesai, dibandingkan harus mengirimkan tenaga yang lulusan SMA atau sarjana untuk mengikuti pendidikan pustakawan secara penuh. Banyak pertimbangan yang menjadi alasan para pimpinan dalam hal ini, misalnya biaya, waktu dan lain sebagainya.

\section{Gedung/Ruang Perpustakaan}

Gedung/ruang perpustakaan belum memperoleh tempat yang terhormat di lingkungan pemerintah kabupaten, sekolah, maupun desa. Gedung/ruang perpustakaan pada umumnya berada dalam keadaan yang memprihatinkan dan terletak di tempat yang "terbelakang", “tersembunyi", dan tidak strategis. Bahkan untuk ruang perpustakaan sekolah biasanya hanya memanfaatkan "ruangan

\footnotetext{
${ }^{7}$ Sutarno N.S. 2005. Tanggungjawab Perpustakaan Dalam Mengembangkan Masyarakat Informasi. Jakarta : Panta Rei.h. 46.
}

sisa" yang ada di lingkungan sekolah. Jika ada perluasan kelas, boleh jadi "ruangan sisa" inipun akan digusur.

\section{Koleksi Bahan Pustaka yang Terbatas}

Kelemahan utama perpustakaan selama ini adalah minimnya pengadaan bahan pustaka baru setiap tahun. Pengadaan bahan pustaka baru sangat berguna untuk menyegarkan koleksi bahan pustaka yang ada, sekaligus untuk menggantikan bahan pustaka yang sudah kadaluwarsa untuk distock opname. Selain masalah keterbatasan anggaran pengadaan, masalah yang sering muncul adalah penyusunan judul buku untuk perpustakaan yang lebih mengedepankan mentalitas proyek dengan mengambil judul buku hanya dari satu penerbit yang memberikan komisi tertinggi. Atau Perpustakaan hanya pasrah seratus persen kepada toko/distributor buku untuk pengadaan bahan pustaka. Model pengadaan buku yang demikian hanya akan menghasilkan "perpustakaan yang membodohkan".

\section{Minat Baca Masyarakat}

Minat baca masyarakat yang rendah hendaknya tidak dijadikan "legitimasi" atau alasan pembenaran bagi terpuruknya dunia perpustakaan secara umum. Kehadiran perpustakaan memang diharapkan untuk meningkatkan minat baca masyarakat. Karena itu jika minat baca masyarakat kita tidak kunjung meningkat, maka hal ini merupakan indikator adanya kebijakan yang salah terhadap perpustakaan di tanah air. Hal ini terjadi karena kebutuhan masyarakat akan perpustakaan belum seperti kebutuhan mereka akan profesi yang lain. Mereka lebih cenderung untuk memenuhi kebutuhan sosial ekonomi terlebih dahulu sebelum menjadikan perpustakaan sebagai prioritas utama mereka. Suwarno mengatakan bahwa perpustakaan masih merupakan keinginan (wants) dari pada kebutuhan (needs) bagi sementara orang. Ini artinya bahwa 
kesadaran dan kepentingan mereka terhadap perpustakaan sebagai sumber informasi mulai ada, mulai menggejala dan berkembang tetapi belum menjadi prioritas yang utama. ${ }^{8}$ Siswa biasanya mau berkunjung ke perpustakaan manakala terbentur dengan keadaan yang memaksa, misalnya karena ada tugas dari guru, atau menyelesaikan tugas, sehingga mereka baru buru-buru ke perpustakaan. Akan berbeda manakala ketika perpustakaan sudah menjadi kebutuhan bagi siswa, mereka akan datang ke perpustakaan baik ada ataupun tidak ada tugas dari guru. Di satu sisi menjadikan perpustakaan yang representatif dan layak digunakan oleh masyarakat luas juga bukan sesuatu yang mudah dan menjadi tantangan bagi para pustakawan sebagai motor penggerak kemajuan perpustakaan.

Banyak alasan kondisi perpustakaan di sekolah mengalami kondisi miris seperti diuraikan di atas. Selain belum adanya pemahaman tentang pentingnya literasi informasi oleh pengambil kebijakan, baik pemerintah maupun manajemen sekolah, faktor biaya, koleksi perpustakaan, ruang bangunan dan lainnya belum mendapatkan perhatian yang selayaknya.

Pada dasarnya perpustakaan adalah pustakawannya. Sehingga semua perubahan atau perkembangan sebuah perpustakaan selalu berawal dari diri pustakawannya. Keberhasilan dalam mencerdaskan generasi penerus bangsa khususnya dalam hal melek informasi, yaitu generasi yang mampu menyadari kapan informasi diperlukan dan ia juga mempunyai kemampuan untuk menemukan, mengevaluasi dan menggunakan informasi tersebut secara efektif, sangat tergantung pada kualitas sumber daya pustakawan sekolah. Kualitas di sini tidak hanya terbatas dalam kemampuan dalam

${ }^{8}$ Suwarno, W. 2010. Ilmu Perpustakaan dan Kode Etik Pustakawan. Jakarta: Arruz Media. menguasai pengetahuan saja. Tetapi juga mampu memahami peran serta perubahan yang terjadi secara cepat. ${ }^{9}$ Kondisi perpustakaan sekolah seperti digambarkan di atas menunjukkan bahwa kualitas sumber daya pustakawan masih mengalami keterbatasan baik dalam menguasai pengetahuan ataupun dalam penyesuaian dalam perubahan. Jika keterbatasan sumber daya pustakawan tidak menjadi prioritas, dapat mejadi faktor penghambat dalam mendukung keberhasilan dalam usaha mempersiapkan generasi bangsa berkompetisi dalam era globalisasi.

Idealnya, perpustakaan harusnya bisa berperan sebagai "jantung sekolah" sebagai sumber informasi/pengetahuan. Peserta didik yang belajar di sekolah, selain mendapatkan ilmu pengetahuan di kelas yang disampaikan dalam proses belajar mengajar, juga bisa memperoleh pengetahuan yang mendukung ilmu pelajaran yang disampaikan oleh pendidik di kelas. Perpustakaan yang ideal pada dasarnya adalah sebuah perpustakaan yang mampu memberdayakan masyarakat. Perpustakaan yang mampu melakukan revolusi minat baca pada masyarakat. Mampu mengubah karakter masyarakat dari tidak suka membaca menjadi suka membaca. Mengubah masyarakat tuna informasi menjadi masyarakat yang berliterasi atau melek informasi.

Untuk itu sebuah perpustakaan yang ideal harus memiliki karakteristik sebagai berikut:

\section{Struktur kelembagaan yang kuat}

Undang-Undang Nomor 43 Tahun 2007 tentang Perpustakaan hanya mengatur kelembagaan perpustakaan secara normatif. Selama ini aspek kelembagaan perpustakaan masih belum jelas, masih menumpang pada

${ }^{9}$ Sutiarso, B. 2003. Perpustakaan Khusus dan Hak Memperoleh Informasi. Jakarta: Perpustakaan Nasional. 
peraturan perundangan lain. Untuk mewujudkan aspek kelembagaan yang kuat, peraturan pelaksana (dalam bentuk Peraturan Pemerintah) perlu secara tegas menentukan status eselon bagi masing-masing jenis perpustakaan. Perpustakaan umum provinsi berbentuk badan (eselon II A), perpustakaan umum kabupaten/kota berbentuk kantor (eselon III A), perpustakaan umum kecamatan berbentuk UPTD (eselon IVA), perpustakaan desa dan sekolah bereselon IV B. Dengan aturan semacam ini perpustakaan akan lebih diperhatikan oleh pemerintah daerah dan peluang untuk mendapat anggaran yang memadai akan semakin besar.

\section{Memiliki desain ruang yang menarik}

Selama ini ruang perpustakaan terkesan sebagai ruang yang serius dan kaku. Padahal perpustakaan dapat didesain dengan menarik dan terkesan santai. Perpustakaan dapat didesain seperti tata ruang sebuah kafe. Penuh pernikpernik dan warna yang kontras. Perpustakaan juga dapat menghadirkan taman dalam ruang baca. Kehadiran taman ini diharapkan akan semakin membuat pemustaka betah untuk melakukan aktivitas membaca, diskusi, belajar, dan mendengarkan musik di perpustakaan.

Desain ruang yang menarik tak harus mahal. Semua jenis perpustakaan dari yang besar, menengah, bahkan yang tergolong paspasan dapat melakukan hal ini. Perpustakaan yang sederhana jika melakukan desain interior yang optimal akan mampu mengubah citra perpustakaan menjadi tempat yang menarik untuk dikunjungi sekaligus dirindukan oleh penggemarnya.

3. Memiliki koleksi yang variatif sesuai keinginan pemustaka

Semakin bervariasi koleksi sebuah perpustakaan akan semakin menarik hati pemustaka. Menu sajian perpustakaan yang lengkap akan berpeluang besar untuk menghadirkan pemustaka dari berbagai lapisan masyarakat. Perpustakaan hadir untuk mendobrak belenggu yang merantai minat baca masyarakat. Belenggu minat baca masyarakat bersumber pada tiga hal. Pertama, belenggu genetika. Anak-anak yang dibesarkan dalam lingkungan keluarga yang tidak suka membaca cenderung akan melahirkan anak-anak yang juga tidak suka membaca. Inilah yang disebut dengan tingkah laku imitasi. Seorang anak akan meniru kebiasaan orang tua. Kedua, belenggu sekolah. Orientasi pendidikan di sekolah yang saat ini mengutamakan kelulusan dalam ujian akhir nasional secara tidak langsung akan mematikan minat baca peserta didik. Demi menggapai kelulusan dalam beberapa mata pelajaran yang di -UN- kan, peserta didik menempuh cara praktis dengan mengikuti bimbingan belajar model "drilling soal". Model pembelajaran semacam ini memasung kreativitas dan inovasi peserta didik yang hanya bisa didapat dengan proses membaca. Ketiga, belenggu pergaulan. Pergaulan memiliki pengaruh yang cukup besar untuk membentuk karakter seseorang. Teman bermain di sekolah maupun di rumah yang tidak suka membaca akan mengakibatkan seseorang juga tidak suka membaca.

Ketiga macam belenggu di atas akan mampu dibuka oleh perpustakaan jika perpustakaan bersikap permisif dan terbuka terhadap segala hobi, kesenangan, dan kebiasaan yang ada di masyarakat. Perpustakaan ideal ialah perpustakaan yang mampu melakukan pendekatan kepada masyarakat untuk membangkitkan potensi membaca yang ada di masyarakat. Pendekatan ini disesuaikan dengan kegemaran, hobi, kesenangan, dan kebiasaan yang ada di masyarakat.

4. Peningkatan kualitas dan kuantitas pustakawan 
Pustakawan yang berkualitas ialah pustakawan yang mampu berperan sebagai agen informasi, ilmuwan, dan pendidik. Sebagai ilmuwan, pustakawan harus mampu memberdayakan informasi bukan sekadar melayankan informasi. Alayyubi (2001) mengungkapkan bahwa pustakawan yang ideal selain profesional ia juga seorang ilmuwan. Selain itu salah satu kendala utama dalam pengembangan perpustakaan di tanah air adalah masih minimnya jumlah pustakawan. Cukup banyak perpustakaan sekolah yang belum memiliki tenaga pustakawan. Pemerintah perlu menyelesaikan masalah ini dengan mengangkat pustakawan kontrak. Kalau untuk memenuhi kekurangan tenaga pengajar pemerintah mengangkat guru kontrak, apa salahnya jika sekarang pemerintah mengangkat pustakawan kontrak. Karena kebutuhan dunia pendidikan terhadap tenaga pengajar hakekatnya sama pentingnya dengan kebutuhan perpustakaan sekolah terhadap pustakawan.

\section{Mempunyai layanan yang berkualitas}

Karakteristik layanan yang baik ini dapat dirangkum dalam akronim COMFORT, yaitu Caring (peduli), Observant (suka memperhatikan), Mindful

hati/cermat), Friendly (ramah), Obliging (bersedia membantu), Responsible (tanggung jawab), dan Tacful (bijaksana). Untuk mewujudkan hal di atas layanan otomasi perpustakaan merupakan suatu keniscayaan. Biaya bukanlah penghalang karena saat ini sudah ada program otomasi perpustakaan yang bersifat open source, seperti PS Senayan.

Literasi Informasi, Pustakawan (Sekolah) dan Tantangan Globalisasi

Peradaban yang berliterasi selalu ditandai dengan kepedulian yang tinggi terhadap perpustakaan. Perpustakaan selalu menjadi transportasi literasi ketika suatu peradaban mencapai puncak keemasan, dan pustakawan adalah transporter atau agennya. Sejarah perkembangan ilmu pengetahuan dan teknologi sepanjang peradaban manusia tidak dapat lepas dari perpustakaan. Literasi informasi merupakan jiwa sebuah perpustakaan. Perpustakaan Nasional RI melukiskan kemampuan informatif ini dalam logonya. Buku terbuka melambangkan sumber ilmu pengetahuan yang senantiasa berkembang. Nyala obor melambangkan pelita dalam usaha mencerdaskan kehidupan bangsa. Dua tangan terkatup dengan lima jari menopang melambangkan ilmu pengetahuan baru dapat dicapai melalui pembinaan pendidikan seutuhnya dengan ditunjang oleh sarana pustaka yang lengkap. Lima dasar penunjang dan lima sinar memancar melambangkan dasar falsafah Pancasila dalam ilmu pengetahuan menghasilkan manusia Indonesia seutuhnya yang berguna bagi nusa dan bangsa.

Untuk menjadi agen literasi, pustakawan harus memiliki kemampuan mengelola informasi yang mencakup hal-hal sebagai berikut.

\section{(1) Collecting of information}

Mengumpulkan tidak lagi berarti harus menyimpan dalam satu ruangan/gedung tertentu tetapi tahu dimana informasi berada dan bagaimana mengaksesnya sesuai yang dibutuhkan pemustaka sasaran. Oleh karenanya Pustakawan harus memiliki: pengetahuan tentang sumber-sumber informasi, pengetahuan, keterampilan, sikap perilaku penelusuran informasi, pengetahuan, keterampilan, sikap perilaku penggunaan/pengoperasian teknologi informasi dan komunikasi, pengetahuan, keterampilan, sikap perilaku mengenal pemustaka sasaran dan kebutuhan informasinya. Stueart dan Moran menjelaskan bahwa telah terjadi pergeseran paradigm pada sumbersumber informasi seperti berikut; jika dulu pepustakaan harus memiliki sendiri koleksinya 
dan disimpan dalam satu bentuk media (cetak), maka dewasa ini koleksi pepustakaan juga ada yang bersifat virtual dan disimpan dalam bebagai bentuk media (cetak dan non cetak). ${ }^{10}$ Perubahan ini juga memerlukan kesiapan mental untuk berbagi informasi dengan yang lain juga kesadaran adanya desentralisasi informasi. Literasi informasi juga merupakan kemampuan penting yang harus dimiliki pustakawan agar dapat merujuk informasi yang akurat.

\section{(2) Processing of information}

Memproses atau mengolah informasi berarti membuat informasi yang dibutuhkan mudah ditemukan kembali oleh pemustaka sasaran. Sistem informasi apapun yang digunakan prinsipnya adalah user friendly. Oleh karenanya pustakawan harus memiliki pengetahuan, keterampilan, sikap perilaku pengolahan informasi, seperti katalogisasi, klasifikasi baik secara manual maupun berbasis teknologi. Pustakawan juga harus memiliki pengetahuan, keterampilan, sikap perilaku penggunaan/pengoperasian teknologi informasi dan komunikasi.

\section{(3) Disseminating of information}

Menyebarkan informasi berarti memberikan layanan informasi seperti yang diinginkan pemustaka sasaran yang diperoleh melalui riset pasar. Oleh karenanya pemustaka harus memiliki pengetahuan, keterampilan, sikap perilaku melaksanakan penelitian/kajian/ identifikasi pemustaka guna memperoleh gambaran yang jelas tentang karakteristik pemustaka sasaran sehingga dapat dirancangkan model layanan informasi yang sesuai dan tepat sasaran. Selain itu pustakawan harus memiliki pengetahuan, keterampilan, sikap perilaku marketing agar produk perpustakaan, baik itu berbentuk barang, jasa, dan ide yang

${ }^{10}$ Stueart, R.D. \& Moran, B.B. 2002. Library and Information Center Management. $6^{\text {th }} . e d$. Westport: Greenwood.h.8-9. disediakan/ditawarkan diketahui dan dimanfaatkan pemustaka sasaran. Pergeseran paradigm layanan informasi yang semula hanya pasif menyimpan informasi/koleksi pustaka, menjadi aktif menekankan pada nilai tambah, kekhususan, keunikan dari layanan informasi/koleksi pustaka yang disediakan/ditawarkan. Pergeseran paradigm juga terjadi pada orientasi pemustaka, dimana kebutuhan dan keinginan mereka menjadi fokus dari semua perencanaan, implementasi, dan evaluasi kegiatan perpustakaan. ${ }^{11}$ Seperti juga dijelaskan oleh Roberts and Rowley (2004) bahwa "collecting data and information on customers provide basis for forming groups or segments of customers, so that it is possible to consider their different expectations, needs and value sets and to respond accordingly".

Selanjutnya pengetahuan dan keterampilan komunikasi baik dalam bentuk komunikasi interpersonal, kelompok, organisasi ataupun massa juga harus dimiliki pustakawan sebagai upaya menjalin hubungan dan membangun kesamaan makna dengan cara yang sesuai dengan stakeholder. Roberts and Rowley (2004) menjelaskan, bahwa konstruksi makna bersama yang dibangun lewat pertukaran simbol baik verbal maupun non-verbal, secara langsung ataupun melalui media ditujukan untuk memenuhi harapan pemustaka sasaran. Seperti dijelaskan oleh Totterdell bahwa "library and information staff need to be polite (but never obsequious on the one hand or patronizing on the other), friendly (but always professional) and always able to behave in a courteous, patient and tactful manner". Selanjutnya Totterdel menambahkan, bahwa "library and information staff need to give the user their complete attention - with proper but not

${ }^{11}$ Stueart, R.D. \& Moran, B.B. 2002. Library and Information Center Management. $6^{\text {th }} . e d$. Westport: Greenwood.h.10-11. 
excessive eye contact - during the interaction". ${ }^{12}$

Membangun pemustaka yang literat juga merupakan hal paling penting dari layanan perpustakaan/informasi yang dapat dilakukan melalui kegiatan-kegiatan yang kreatif, inovatif dan mengedepankan selera pemustaka. Prinsip one game one customer dapat diadaptasi untuk memberikan kepuasan layanan perpustakaan/informasi. Menjadi bagian dari sebuah komunitas atau kelompok yang memiliki kebutuhan dan peminatan yang sama menjadi penting ketika pengetahuan dikonstruksi bersama orang lain. Dengan kata lain menjadi literat merupakan usaha yang dibangun bersama orang lain. Oleh karenanya pustakawan harus menjadi kreator,fasilitator, dan motivator bagi terbangunnya pemustaka-pemustaka yang literat. $^{13}$

\section{(4) Preserving of Information}

Menyelamatkan hasil pikir manusia yang terekam dan terdokumentasikan melalui caracara yang aman bagi kepentingan pengembangan pengetahuan dan peradaban juga menjadi tanggung jawab pustakawan. Mengoptimalkan usia pendayagunaan koleksi pustaka/informasi dari generasi satu ke generasi lain menjadi penting mengingat manusia mengembangkan diri melalui pengetahuan yang diperolehnya dari hasil pikir manusia-manusia terdahulu. Oleh karenanya pustakawan harus memiliki pengetahuan dan ketrampilan preservasi preventif yang memadai mulai dari seleksi akuisisi, penyimpanan, dan diseminasi koleksi pustaka/informasi untuk menghindari atau meminimalkan kerusakan.

\footnotetext{
${ }^{12}$ Totterdell, A. 2005. Library and Information Work. London: Facet.h. 99.

13 Damayani, N.A. 2011. Komunitas Literer Bandung: Studi Fenomenologi pada Individu yang Terlibat dalam Pergerakan Literasi Informasi. Disertasi. Program Pasca Sarjana Universitas Padjadjaran.
}

Melalui pemaparan tentang kompetensi pustakawan maka dapat disimpulkan bahwa kompetensi berupa kemampuan yang harus dimiliki pustakawan terdiri dari hard skill dan soft skill. Hard skill berupa kemampuan kerja mengelola informasi (collecting, processing, disseminating, preserving) secara teknis, termasuk berbasis teknologi informasi dan komunikasi, bagi terselenggaranya kegiatan layanan perpustakaan/ informasi. Adapun soft skill berupa kemampuan membangun relasi, interaksi dan bekerjasama dengan dengan orang lain dalam mengelola informasi (collecting, processing, disseminating, preserving), seperti communication skill, interpersonal skill, entrepreneurship, leadership.

Di perpustakan sekolah, disamping sebagai pustakawan, dapat pula menjadi guru, minimal sebagai mitra. Dalam banyak hal pustakawan memainkan berbagai peran (berperan ganda) yang dapat disingkat EMAS. Sebagai edukator (pendidik), pustakawan dalam melaksanakan tugasnya harus berfungsi dan berjiwa sebagai pendidik. Sebagai pendidik,ia harus melaksanakan fungsi dan berjiwa sebagai pendidik,ia harus melaksanakan fungsi pendidikan yaitu mendidik, mengajar dan melatih. Mendidik adalah mengembangkan keterampilan. Oleh karenanya, pustakawan harus memiliki kecakapan mengajar, dan melatih adalah membina dan mengembangkan keterampilan. Oleh karenanya, pustakawan harus memiliki kecakapan mengajar, melatih dan mengembangkan, baik para pegawai maupun para pengguna jasa yang dilayaninya. Sebagai seorang pustakawan pendidik, pustakawan pendidik, pustakawan juga harus memahami prinsip-prinsip yang dikembangkan oleh Ki hajar Dewantara, yaitu "Ing madya mangun karsa". Pustakawan harus membangkitkan semangat berswakarsa dan 
berkreasi pada orang-orang yang dilayaninya. "Tut wuri handayani" yakni pustakawan harus mampu mendorong orang-orang yang dilayaninya agar berani berjalan di depan dan sanggup bertanggung jawab.

\section{Pustakawan Sekolah sebagai Agen Literasi Informasi di Indonesia}

Pada hakekatnya pustakawan adalah "manajer informasi" yang mengelola informasi pada satu sisi, dengan pengguna informasi pada sisi lain. Informasi yang banyak terdapat dalam berbagai wadah yang jumlah selalu bertambah harus dikelola dengan baik. Kebutuhan informasi pengguna merupakan dasar pengelolaan informasi. Pustakawan harus mampu menyusun, melaksanakan, dan mengevaluasi program perpustakaan, serta dapat melakukan analisis atas hasil yang telah dicapai hasil yang lebih baik. Oleh karena itu, seorang pustakawan harus mempunyai pengetahuan yang luas di bidang organisasi, sistem dan prosedur ke dalam kegiatan-kegiatan nyata, sehingga akan dapat meningkatkan kualitas kerja, berdaya guna, berhasil guna dan tepat guna.

Perpustakaan masa depan bukanlah peningkatan perpustakaan yang dilengkapi dengan perangkat yang sangat canggih tanpa adanya minat baca masyarakat sebagai pendukung utama. Namun perpustakaan masa depan adalah perpustakaan yang lengkap dengan segala kecanggihan teknologinya yang dapat memenuhi kebutuhan dan menarik minat baca masyarakat. Dengan begitu pengarahan perpustakaan yang sebenarnya adalah penyesuaian terhadap karakter dan kemampuan literasi informasi masyarakat bukan terus menambah kecanggihan teknologi di dalamnya tanpa memperhatikan yang dimiliki masyarakat.

Munculnya beragam pilihan informasi yang tersedia baik itu tercetak, elektronik, image, spatial, suara, visual, maupun yang bersifat numerikal membuat literasi informasi menjadi semakin penting di era informasi seperti sekarang ini. Permasalahan yang terjadi bukanlah tidak tersedianya informasi yang cukup, tetapi karena begitu banyaknya informasi yang tersedia dalam berbagai format sehingga menimbulkan pertanyaan tentang keaslian, kesahihan, dan kebenarannya. Selain itu, masalah lain yang muncul dalam berinteraksi dengan informasi adalah waktu yang tidak pernah cukup dan sulit mengetahui informasi apa saja yang tersedia. Healy mengungkapkan bahwa ada dua masalah tama dalam informasi yaitu bagaimana memiliki waktu yang cukup untuk mengaksesnya dan bagaimana mengetahui informasi apa yang tersedia saat ini. ${ }^{14}$

Boyer menyatakan bahwa memberdayakan peran informasi merupakan tujuan penting dari pendidikan. Ia menyatakan, informasi merupakan sumber yang sangat berharga. Pendidikan harus dapat memberdayakan semua orang untuk mendapatkan informasi yang sesuai dengan kebutuhannya. ${ }^{15}$ Memang disadari bahwa untuk merubah informasi menjadi pengetahuan bukanlah perkerjaan yang mudah. Proses pembejaran sangat berpengaruh untuk merubah informasi menjadi pengetahuan. Pengaruh proses itu akan semakin kuat bila didukung oleh kompetensi literasi informasi yang baik. Manfaat kompetensi literasi informasi dalam dunia pendidikan di sekolah adalah:

a. Menyediakan metode yang telah teruji untuk dapat memandu siswa kepada berbagai sumber informasi yang terus berkembang. Sekarang ini individu berhadapan dengan informasi yang beragam dan berlimpah.

${ }^{14}$ Healy, L.W. 2002. "The Voice of the User: Where Students and Faculty Go for Information." http://www.educause.edu/ir/libran/pow

15 Boyer, E.L. 1997. New Technologies and the Public Interest. Selected Speeches 1979-1995. Princeton, N.J.: Carnegie Foundation for the Advancement of Teaching. pp. 137-142. 
Informasi tersedia melalui perpustakan, sumber-sumber komunitas, organisasi khusus, media, dan internet.

b. Mendukung usaha nasional untuk meningkatkan kualitas pendidikan. Lingkungan belajar yang proaktif mensyaratkan setiap siswa memiliki kompetensi literasi informasi. Dengan keahlian informasi tersebut maka siswa akan selalu dapat mengikuti perkembangan bidang ilmu yang dipelajarinya.

c. Menyediakan perangkat tambahan untuk memperkuat isi pelajaran. Dengan kompetensi literasi informasi yang dimilikinya, maka siswa dapat mencari bahan-bahan yang berhubungan dengan perkuliahan sehingga dapat menunjang isi pelajaran tersebut.

d. Meningkatkan pembelajaran seumur hidup. Meningkatkan pembelajaran seumur hidup adalah misi utama dari institusi pendidikan. Dengan memastikan bahwa setiap individu memiliki kemampuan intelektual dalam berpikir secara kritis yang ditunjang dengan kompetensi informasi yang dimilikinya maka individu dapat melakukan pembelajaran seumur hidup secara mandiri (California State University, 2001).

Literasi informasi diperlukan untuk meningkatkan kualitas diri dalam rangka belajar seumur hidup. Ketika seseorang bermaksud meningkatkan taraf hidupnya, maka dia memerlukan sesuatu yang lebih dari dirinya yaitu perkembangan diri, baik ketrampilan, pendidikan atau kinerja yang lebih baik. Proses untuk menjadi lebih adalah sesuatu yang dapat dicapai melalui proses belajar. Kemampuan untuk dapat belajar secara mandiri akan membuat proses yang dilalui lebih mudah dengan berbekal kemampuan literasi informasiLiterasi informasi diperlukan untuk meningkatkan kualitas diri dalam rangka belajar seumur hidup. Ketika seseorang bermaksud meningkatkan taraf hidupnya, maka dia memerlukan sesuatu yang lebih dari dirinya yaitu perkembangan diri, baik ketrampilan, pendidikan atau kinerja yang lebih baik. Proses untuk menjadi lebih adalah sesuatu yang dapat dicapai melalui proses belajar. Kemampuan untuk dapat belajar secara mandiri akan membuat proses yang dilalui lebih mudah dengan berbekal kemampuan literasi informasi.

Literasi informasi membentuk dasar bagi pembelajaran seumur hidup. Hal ini berlaku umum bagi semua disiplin, bagi semua lingkungan belajar, dan bagi semua tingkatan pendidikan. Dengan literasi informasi, siswa dapat menguasai isi materi dan memperluas penelitian, mengarahkan diri sendiri, serta memiliki kontrol yang lebih besar terhadap proses pembelajaran.

\section{Penutup}

Dampak yang sangat nyata dari kemajuan teknologi informasi adalah terjadinya situasi yang disebut dengan ledakan informasi, yaitu situasi yang setiap orang dapat menerima informasi apa-pun, kapan-pun dan dari manapun tanpa batas. Hal ini meniscayakan bagi setiap orang untuk memiliki keterampilan dan pengetahuan melakukan pencarian informasi yang benar, sehingga akan diperoleh informasi yang benar-benar sesuai dengan kebutuhannya. Agar proses pemenuhan kebutuhan informasi berhasil dengan baik, maka seseorang perlu memahami konsep literasi informasi.

Kompetensi literasi informasi merupakan keterampilan esensial di abad digital bagi pengguna perpustakaan akademis yang terdiri dari guru dan siswa. Apalagi saat ini dunia persekolahan dibanjiri dengan masuknya generasi digital native. Siswa dengan digital native memiliki karakteristik yang berbeda dalam memilih sumber media pencarian dan menggunakan informasi. Mereka sangat terampil dalam memilih gadget dan memanfaatkannya untuk menelusur dan 
menggunakan informasi yang dibutuhkan, namun secara umum masih rentan dengan kebenaran informasi yang mereka dapatkan. Fenomena ini menambah panjang tugas dan tututan yang harus diemban oleh para pengelola perpustakaan sekolah (pustakawan sekolah).

Pengembangan kemampuan literasi informasi merupakan sebuah life skill yang harus dikembangkan dan dimiliki oleh tenaga pengelola perpustakaan. Jika ditelusur lebih dalam akan didapati penyebab dari rendahnya kemampuan literasi informasi yaitu kurang tersentuhnya kompetensi dari tenaga pengelola perpustakaan oleh kebutuhan literasi informasi dari kurikulum pendidikan perpustakaan dan yang terjadi juga belum adanya sinergi dari pemerintah dan persekolahan untuk mengembangkan sumber daya manusia di perpustakaan untuk mengelola kemampuan tersebut. Sedianya di setiap sekolah memiliki pustakawan/tenaga pengelola perpustakaan yang secara berkala berupaya untuk meningkatkan kemampuan dalam memberikan pelayanan literasi informasi kepada para pemustakanya.

Literasi memiliki fungsi penting dalam kehidupan. Kesadaran berliterasi akan mengantarkan sebuah peradaban pada kedudukan yang terhormat. Bangsa yang literate adalah bangsa yang mampu menjawab tantangan zaman. Sebaliknya, bangsa yang tidak literate akan menjelma menjadi sebuah bangsa lemah. Bangsa lemah ini tidak akan pernah mampu merespon tantangan dan rintangan di masa depan, khususnya tantangan globalisasi, termasuk pasar bebas Asia yang sebentar lagi diberlakukan di Indonesia. Karena pada dasarnya perpustakaan adalah pustakawannya, sehingga semua perubahan atau perkembangan sebuah perpustakaan selalu berawal dari diri pustakawannya. Dengan kata lain pustakwan selayaknya bertransformasi menuju pola pikir dan pola tindak baru yang mendukung perubahan tersebut.

\section{REFERENSI}

\section{Buku dan Jurnal}

Boyer, E.L. 1997. New Technologies and the Public Interest. Selected Speeches 1979-1995. Princeton, N.J.: Carnegie Foundation for the Advancement of Teaching. pp. 137-142.

Damayani, N.A. 2011. Komunitas Literer Bandung: Studi Fenomenologi pada Individu yang Terlibat dalam Pergerakan Literasi Informasi. Disertasi. Program Pasca Sarjana Universitas Padjadjaran.

Departemen Pendidikan Nasional. 2007. Kamus

Besar Bahasa Indonesia. Jakarta : Balai Pustaka.

Facet, R. \& Richard, E. 2004. Foundations of Library and Information Science. 2d.ed. New York: Neal-Schuman.

Friedman, T.L. 2006. The World is Flat: Sejarah Ringkas Abad Ke-21. Jakarta: Dian Rakyat.

Guenia, J. 2003. Building Bridges: The Role Of

The System Librarian in A University. (Emerald, 2003), Library Hi Tech. Vol. 21 Number 32003.

Gunawan, A.W. 2008. Tujuh Langkah Literasi Informasi: Knowledge Management. Jakarta: Universitas Atma Jaya.

Hasugian. J. 2008. Urgensi Literasi Informasi dalam Kurikulum Berbasis Kompetensi di Perguruan Tinggi Pustaha: Jurnal Studi Perpustakaan dan Informasi, Vol. 4, No.

2, Desember 2008

Perpustakaan Nasional RI. 2007. UndangUndang Republik Indonesia Nomor 43 tahun 2007 Tentang Perpustakaan.

Rachmadi, F. 1988. Informasi dan Komunikasi dalam Percaturan Internasional. Bandung: Alumni. 
Samiyono, D. 1994. Menyongsong Automasi

Layanan Perpustakaan: Ditinjau dari Segi Manajemen Pemasaran Informasi. Solo: Universitas Sebelas Maret.

Setiarso, B. 2003. Perpustakaan Khusus dan Hak Memperoleh Informasi. Jakarta: Perpustakaan Nasional.

Sophiaan, A.R. 1993. Tantangan Media Informasi Islam, Antara Profesionalisme dan Dominasi Zionis. Surabaya: Risalah Gusti.

Stueart, R.D. \& Moran, B.B. 2002. Library and Information Center Management. $6^{\text {th }} . e d$. Westport: Greenwood.

Sudarsono, B. 2007. Literasi Informasi (Information Literacy): Pengantar untuk Perpustakaan Sekolah. Jakarta: Perpustakaan Nasional RI.

Sulistyo, B. 2006. Upaya meningkatkan peran pustakawan dalam mendukung kinerja perpustakaan. Media Pustakawan: Media Komunikasi Antar Pustakawan. 12 (3-4) September/Desember 2005 : 1112

Sulistyo, B. 1994. Periodisasi Perpustakaan Indonesia. Bandung: Rosdakarya.

Supriyanto, W. 2008. Teknologi Informasi Perpustakaan. Yogyakarta: Kanisius.

Sutarno N.S. 2005. Tanggungjawab Perpustakaan Dalam Mengembangkan Masyarakat Informasi. Jakarta : Panta Rei.

Suwarno, W. 2010. Ilmu Perpustakaan dan Kode Etik Pustakawan. Jakarta: Arruz Media.

Totterdell, A. 2005. Library and Information Work. London: Facet.

Webber \& Johnston, B. 2000. Conception of Information Literacy: new perspective and implications. Journal of Information Science, Vol.26 N0.6, hal. 381-387

\section{Sumber Internet dan Koran}

Anonim. 2010. Ciri-ciri Era Globalisasi Informasi.

http://abdulsalamserbakomunikasi.blogs pot.com/2010/03/ciri-ciri-eraglobalisasi-informasi.html

Anonim. Tt. Information Literacy Models and Ainquiry Learning Models. Sumber: http://ictnz.com/infolitmodels.htm.

Astiwi, P.N. Peningkatan Kemampuan Information Literate Sebagai Basis Pengembangan Menyeluruh Perpustakaan Masa Depan dalam Globalisasi Informasi: Kebutuhan Informasi dalam menentukan Arah Pengembangan Perpustakaan. Majalah Visi Pustaka Vol.13 No.3 - Desember 2011.

http://perpusnas.go.id/MajalahOnlineAd d.aspx?id=165

Bhandary, K.M. Librarian, TUCL. Information Literacy and Librarian's Role. Sumber: http://www.tucl.org.np/infliteracy.htm

Haryanti, T. 2009. Membangun Gerakan Literasi Informasi. http://triniharyanti.blogspot.com/2009/0 5/membangun-gerakan-literacyinformasi.html.

Healy, L.W. 2002. "The Voice of the User: Where Students and Faculty Go for Information."

http://www.educause.edu/ir/libran/pow erpoint/EDU0248c.pps.

Hermanto, B. 2008. Penerapan teknologi informasi untuk meningkatkan mutu layanan perpustakaan Universitas Sebelas Maret. http://pustaka.uns.ac.id/? $\underline{\text { menu}=\text { news\&option=detail } \& \text { nid }=13}$

Widodo. 2012. Peran dan karakteristik pustakawan di era digital library. http://widodostaff.uns.ac.id 